\title{
Postural differences of volleyball players
}

\section{BOROZAN Ion-Silviu1, GRĂDINARU Sorin², MIRON Paul³, PUTA Tiberiu, BOTA Eugen5}

\begin{abstract}
Aim: The paper's purpose is to determine the existence of differences in anthropometric and postural characteristics in specific sport branches, in this case, to find the ergonomic posture for athletes in the area of volleyball. Differences can be used by professional teams and sport clubs in the selection of new athletes, in improving performance monitoring for the active athletes and in determining specific ergonomic position for each sport.

Materials and methods: Participants included in the study were seven active athletes (all male volleyball representatives) aged 16 to 23. They had been involved in a series of non-invasive tests using a postural baro-podometric electronic platform consisting of a pressure plate with 6400 active sensors. This unit examines the pressure orthostatic bipedal (static exam) and balance (stabilometric exam) using Miletrix 2.0 software exams that have produced a number of parameters and indicators. After analyzing and comparing the obtained parameters, analytical and graphical differences were observed between the volleyball athletes' in regard to posture.

Results: The differences occur because of various exercises used in motor development and specific skills needed in each sport.

Conclusion: Proving these differences by using a small number of indicators and parameters, applied on just 7 athletes included in the study, opens new ways and offers new opportunities for further scientific analysis of this field, with the final goal of being able to suggest the best suitable sport for an individual based only on a few, fast, non-invasive measurements, able to tell if an individual suits the ergonomic posture specific for that certain sport.
\end{abstract}

Key words: posture, volleyball, training, postural differences

\section{Rezumat}

Scop: Scopul lucrării este de a determina principalele diferențe posturale ale jucătorilor de volei masculin, evidențiind caracteristici specifice ale mișcărilor și antrenamentelor specifice aparținând acestei ramuri sportive. Diferențele pot fi utilizate de către echipe de profesioniști și cluburi sportive în procesul de selecție a noilor sportivi, la monitorizarea și îmbunătățirea performanțelor sportivilor activi, determinând postura ergonomică specifică pentru fiecare sport. Materiale și metode: Participanții au fost 7 sportivi de performanță activi (toți reprezentatanți ai voleiului masculin) cu vârste cuprinse între 16 și 23 ani. Ei au efectuat o serie de teste non invazive, folosind o platformă baropodometrică posturală electronică alcătuită dintr-o placă de presiune cu 6400 senzorilor activi. Această unitate analizează presiunea ortostatică bipedă (examenul static) și echilibru (examenul stabilometric), folosind software-ul Miletrix 2.0, examene ce au produs o serie de parametri și indicatori, care după ce au fost analizați și comparați s-au observat diferențe de natură analitică și grafică, diferențe posturale evidente dintre sportivii ramurii sportive volei .

Rezultate: Diferențele posturale apar din cauza variatelor exerciții folosite în dezvoltarea motrică și a aptitudinilor specifice necesare în fiecare sport.

Concluzii: Descoperirea acestor diferențe, folosind doar 7 participanți și un număr redus de parametri și indicatori, deschide o oportunitate de a studia științific și mai mult această direcție până când se va găsi o modalitate de a propune cel mai potrivit sport pentru un individ doar prin efectuarea unei serii rapide de măsurari non-invazive, care ne-ar putea spune dacă o anumită persoană se încadrează în postura ergonomică specifică unui anumit sport.

Cuvinte cheie: postură, volei, antrenament, diferențe posturale

\footnotetext{
${ }_{1}^{1}$ Assistant Professor PhD, Politehnica University Timișoara, e-mail: ion.borozan@upt.ro

2 Associate Professor PhD, Physical Education and Sports Faculty, West University of Timișoara

3 Lecturer PhD, Physical Education and Sports Faculty, West University of Timișoara

${ }^{4}$ Lecturer PhD, Physical Education and Sports Faculty, West University of Timișoara

${ }^{5}$ Associate Professor PhD, Physical Education and Sports Faculty, West University of Timișoara
} 


\section{Introduction}

The purpose of this study is to determine the existence of differences in anthropometric and postural characteristics in specific sport branches, in this case, to find the ergonomic posture for athletes in the area of volleyball. Differences can be used by professional teams and sport clubs in the selection of new athletes, in improving the performance of active athletes and in monitoring and determining specific ergonomic positions for each sport. Participants included in the study were seven active athletes (all male volleyball representatives) with ages between 16 and 23 . They had been involved in series of non-invasive tests using a postural baro-podometric electronic platform consisting of a pressure plate with 6400 active sensors. This unit examines the orthostatic bipedal pressure (static exam) and balance (stabilometric exam) using Miletrix 2.0 software exams that have produced a number of parameters and indicators. After analyzing and comparing these parameters certain analytical and graphical differences were observed between the volleyball athletes' in regard to posture. The differences occur because of various exercises used in motor development and specific skills needed in each sport.

Proving these differences by using a small number of indicators and parameters, applied on just 7 athletes included in the study, opens new ways and offers new opportunities for further scientific analysis of this field, with the final goal of being able to suggest the best suitable sport for an individual based only on a few, fast, non-invasive measurements, able to tell if an individual suits the ergonomic posture specific for that certain sport [1].

Because of the biomechanical complexities that occur in the human body the analysis requires static or dynamic models for the development of biomechanical postural conditions or movements of the body. However, modeling biomechanics of the musculoskeletal human is an important step in the implementation of any technical system used to improve mobility of the lower limb or to increase the amplitude in joints in the case of athletes involved in high performance sport. Combining aspects of biomechanics with ergonomics we efficiently offer choices for improving the results achieved by athletes. Such biomechanical modeling of the musculoskeletal applications either concern the medical aspects of human body or pathological situations in the case of orthopedic and locomotor rehabilitation opportunities, either aspects of human performance or biomechanical and ergonomic parameters that can lead to achieving athletic performance.
In the case of sports, biomechanics and ergonomics can help increase performance, both in individual sports and in a team, through the analysis of static, kinematic or dynamic parameters. In this way, the analytical model is the basic, fundamental consideration of any analytical biomechanical effect in developing physical skills (for example, increase the amplitude of articular joints), improving sporting technique and improving the selection method.

Joints of the lower limb, especially the ankle joint is in great demand in many current activities of the locomotor system, because it is involved in body propulsion and shock absorption caused by the impact with the ground during walking, running or jumping. The contact between the foot and the ground has the effect of mechanical stress on the morpho-functional bone-ligament-tendon system, being at the basis of the support and balance system of the whole body, this contact creating both plantar pressure and individual pressure points on each sole; the projection of the center of gravity of the whole body helps observing an individual's main and ideal posture.

The human body is in a constant and slight oscillation around its center of gravity. It is designed from the ground between the two legs (in the middle polygon eighth for lifting and describes an amplitude of $+2 /-2 \mathrm{~cm}$ ). The human body oscillates like a pendulum reversed and pinned to the ground. The postural system has several complementary functions:

- Fight against gravity and maintain a position of rectitude;

- Resisting external forces;

- Location in a structured space that surrounds us;

- Balancing moving, guiding and strengthening movements;

To perform these different functions, our postural system depends on several types of receptors:

- exterior receptors put us in relation to our environment (touch, sight, hearing);

- proprioceptors situated in various parts of our body, in comparison with the group in a given position;

- receptors situated in the dentin and teeth with extraordinary complexity and precision;

- selectors - higher centers that integrate, processes and cognitively analyzed data from the two previous sources.

The base used for keeping the whole body in an orthostatic position is the plantar surface of the foot (the sole).

Sports training aims to prepare the athlete to achieve maximum results in both the sporting activity and in the development of his personality, 
the training process comprising of two factors that require a complex solution:

- Physical preparation - its main content is the development of driving quality (physical), basically: endurance, strength, speed and skill, and the formation of new motion skills

- Technical training - a rational structure of the motor act according to your purpose

Beside these, there is the tactical preparation, psychological and moral theory.

All these factors are directly related to the factors that determine human posture. Each branch and sporting event, through competition rules, has a number of specific motor actions (techniques) that are the basis, and their characteristic motor.

Taking into account these differences between the techniques specific for each sport using the baropodometric platform we want to analyze and compare the postural differences in volleyball athletes. In the present study 5 male volleyball athletes were analyzed. At the same time these athletes were selected to encompass the full range of positions in the game of volleyball players, namely: BL- (Setter); RM (Middle blocker); RN(Outside hitter); VR-l (Opposite); CS (Outside hitter) In this study, our goal is to determine whether there are postural differences among the athletes at an individual level and how these differences might impact on their performance, as well as to determine whether these differences could be used by professional teams and sports clubs in the selection process and in improving performance.

\section{Materials and methods}

\section{a. Static exams}

The investigation determined the average result of fluctuations static body for a period of five seconds, depicting the pressures detected in "support polygon" between the left and the right foot.

The data observed in this examination define "basic parameters" and must be correlated with the morphological data of the foot. The data also provides values such as load distribution, areas of distribution, position of center of pressure of the support polygon as individual limb.

The graphs display a chromatic scale with 10 levels of color (from red to brown) and indicate any kind of tasks (hypo/hyper). The average color of pressure will be determined, in regard to all polygons of both feet.

\section{CoF angle}

It consists of a straight line passing through the centers of each individual pressure foot (points marked $\mathrm{L}$ and $\mathrm{R}$ ). This indicator is used to evaluate the rotations of the stem structure, with particular reference to the rotation of the basin (fig. 1).
It connects the tilt to tilt value of the pelvis and body morphology of both views side [2].

The reference angle is 2 degrees if it is reverseclockwise (left foot behind the right) and -2 degrees if it is i normal (right foot behind your left) [3], [4], [5]. This value of $+2,-2$ degrees is the ideal rotation angle COF.

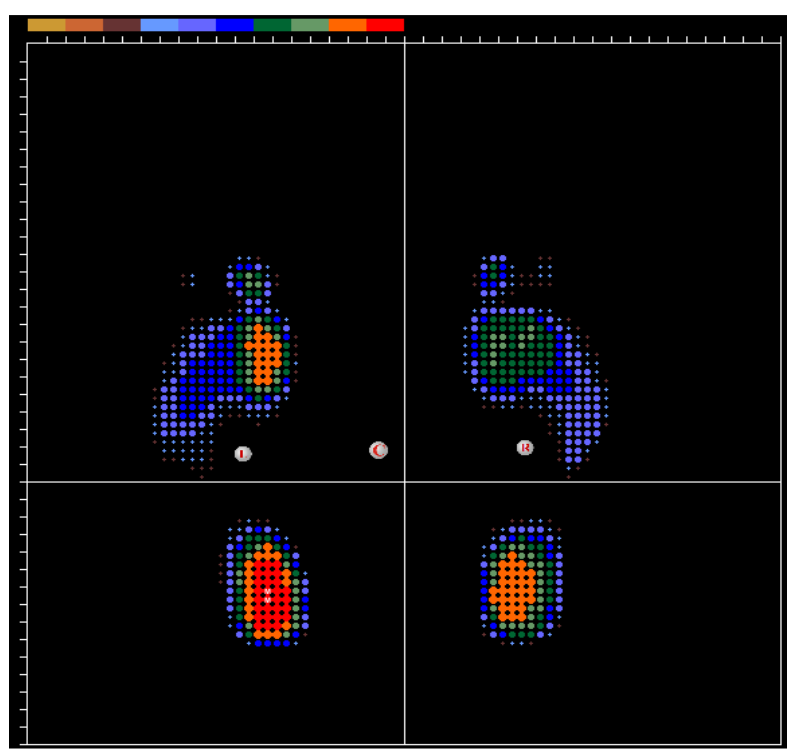

Figure 1. Example of CoF angle image results

We notice differences between athletes only in the area of positive angle values "COF". The closest to the ideal value of approximately 2 degrees was RN, while the shooter was second, highlighting great mobility in motion for both these positions. At the opposite pole lies RM, which is the main shooter and one of the tallest subjects, but a robust, less mobile player, especially when it comes to the joints between the trunk and limbs (fig. 2, 3).

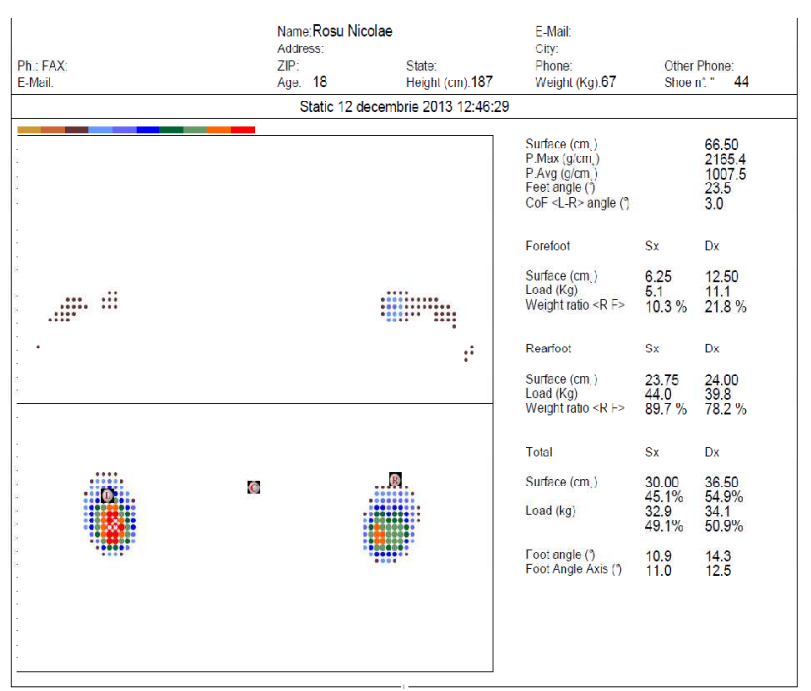

Figure 2. CoF angle lower extremity among volleyball players-result of RN 


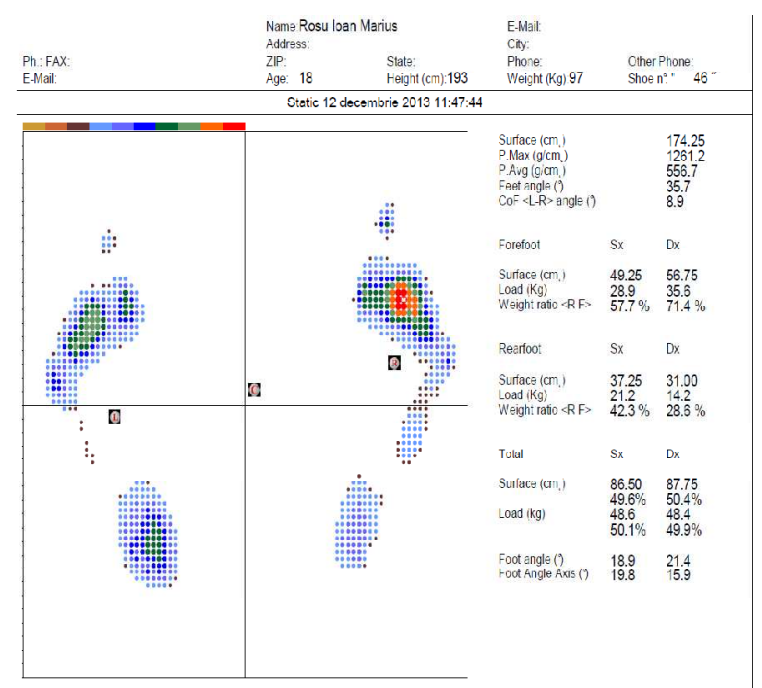

Figure 3. CoF angle upper extremity-result of volleyball player RM

\section{FAA (Foot Angle Axis) legs axis angle}

This angle is calculated as the angle formed by the line beginning between the second and third finger and going up through the center of the heel. If the angle is too small ( 3 or 4 degrees) it indicates an excessive medial position, if it is too high (greater than 15 degrees) it indicates an excessive lateral position. The reference value is around 12 degrees [5].

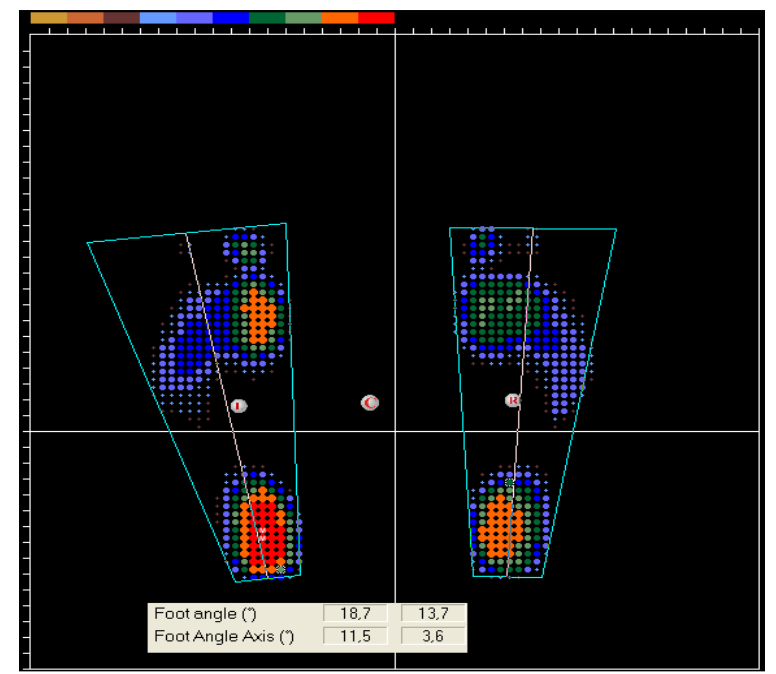

Figure 4. Feet angle axis mean value results

Small differences are observed among athletes in both legs. The bottom line is that all these athletes have very good stability to the side, forming a broad base of stability with both feet. In this case the characteristic differences are very small.

\section{The plantar surface of the feet}

Represents all contact points between the sole and the baropodometric platform (fig. 5).

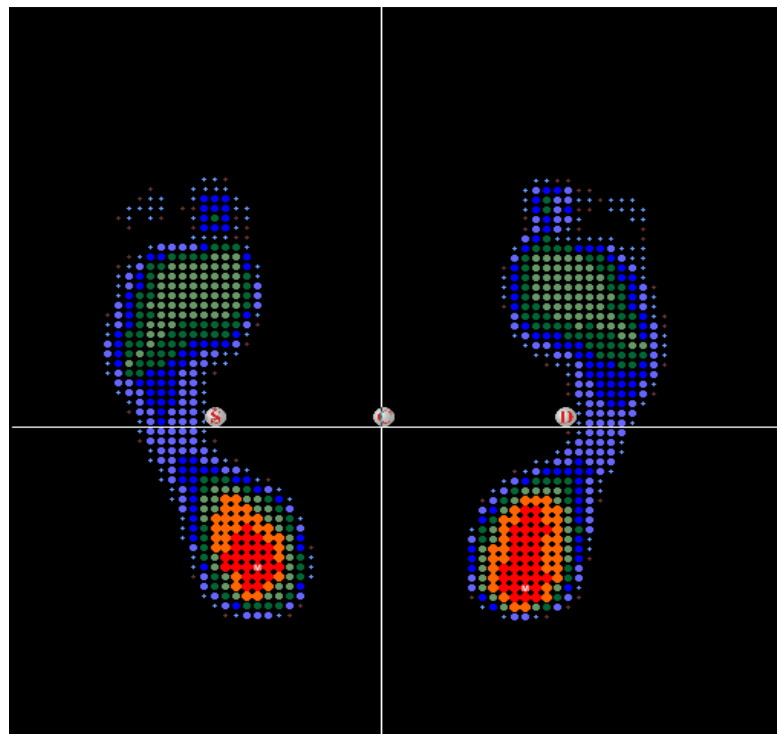

Figure 5. Example of the plantar surface of the feet results sheet

Following comparisons there are considerable differences between athletes regarding this parameter. Differences have also been noted between the centers of gravity and the route between the maximum pressure points of all athletes.

Plantar surface indicators show higher values of approx. $137.75 \mathrm{~cm}^{2}$, the highest value being attributed to the athlete with the biggest size for footwear, for example RM 46. This is closely correlated with specific morphological features (figure 6).

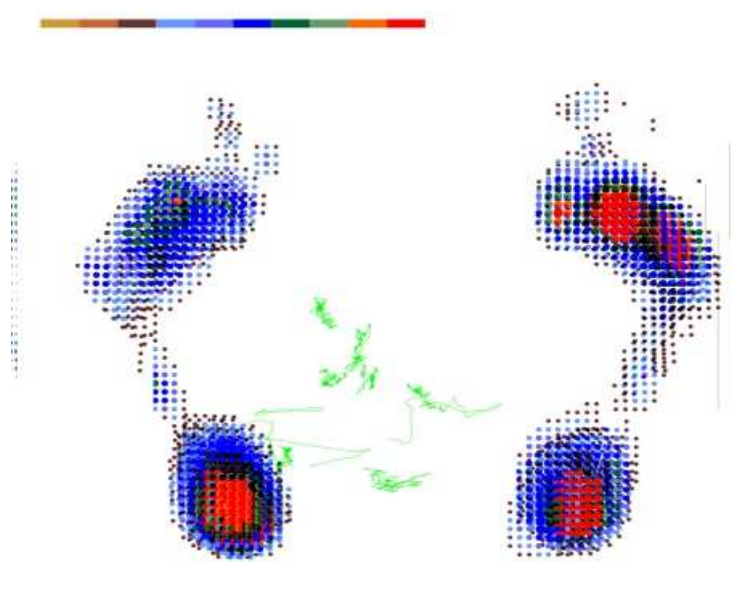

Figure 6. Plantar surface mean value of the tested volleyball players. 


\section{Results}

Differences between the athletes can be seen in plantar areas in a few cases; they are probably due to differences in size between athletes.

From the CoF angle point of view, we notice differences only in the area of positive angle values. The closest to the ideal value of approximately 2 degrees was RN, while the shooter was second, highlighting great mobility in motion for both these positions. At the opposite pole lies RM, which is the main shooter and one of the tallest subjects, but a robust player, less mobile, especially in the joints between the trunk and limbs.

Plantar surface show higher values to approx. $137.75 \mathrm{~cm}^{2}$, the highest value being attributed to the athlete with the biggest shoe size, for example RM 46. This is closely correlated with specific morphological features.

\section{Discussions}

The human body is in a constant and slight oscillation around its center of gravity. It is designed from the ground between the two legs (in the middle polygon eighth for lifting and describes an amplitude of $+2 /-2 \mathrm{~cm}$ ). The human body oscillates like a pendulum reversed and pinned to the ground. The discovery of these differences, using only 7 participants and a limited number of parameters and indicators gives the opportunity to study more this direction until you find a way to indicate the most suitable sport for an individual just by making a rapid series of non-invasive measurement, it could tell if a person falls into that particular sport by the specific ergonomic posture.

Modeling biomechanics of the musculoskeletal human is an important step into the implementation of any technical system to improve the human leg mobility or increase the amplitude joints in high performance sport. Combining the aspects of biomechanics with ergonomics we efficiently offer choices for sports and solutions for improving results achieved by athletes.

\section{Conclusions}

Proving these differences by using a small number of indicators and parameters, applied on just 7 athletes included in the study, opens new ways and offers new opportunities for further scientific analysis of this field, with the final goal of being able to suggest the best suitable sport for an individual based only on a few, fast, non-invasive measurements, able to tell if an individual suits the ergonomic posture specific for that certain sport.

Modeling the biomechanics of the musculoskeletal system is an important step into the implementation of any technical system to improve the human limb mobility or to increase the amplitude of joints in the case of professional sport players. Combining aspects of biomechanics with ergonomics we efficiently offer choices for improving the results achieved by athletes. Such biomechanical modeling of the musculoskeletal applications either concern the medical aspects of human body or pathological situations in the case of orthopedic and locomotor rehabilitation opportunities, either aspects of human performance or biomechanical and ergonomic parameters that can lead to achieving athletic performance.

\section{References}

1. Argeșanu V., Anghel M., Jula M., Comes C., Kulcsar R. (2010). Metode actuale de investigare a statusului postural în medicina dentară, Milenium III Medicine, The International Congress of Medical Days in Banat 15th edition, Timisoara, Romania, vol. 60, nr. 1.

2. Galasso P., Ranieri M., Fiore P., Ianieri G., Megna M., Megna G. (2004). Utilizzo del baropodometro elettronico in ambito riabilitativo e principi di biofeedback pressorio: rilievi preliminari, Bibliografia Diasu, Roma.

3. Hollinshead, W. H. (1969). Functional Anatomy of the Limbs and Back, W. B. Saunders, London.

4. Moretti B., Patella V., Simone C., Ranieri M., Megna G. (2004). La baropodometria elettronica: utilità clinica diagnostica, preventiva e terapeutica, Bibliografia Diasu, Roma.

5. $\quad * * *$ Milletrix software user's manual ed 2.0 